\title{
KEUPAYAAN PENGURUSAN INTELEKTUALISME KANAK-KANAK DALAM KEKUASAAN ANIMASI UPIN DAN IPIN
}

\section{CAPABILITY OF INTELLECTUALISM MANAGEMENT OF CHILDREN IN THE UPIN DAN IPIN ANIMATION EMPOWERMENT}

\author{
Norsaliza Mohd Shuhaini, Mohd Rosli Saludin \& Azhar Hj.Wahid \\ Institut Peradaban Melayu \\ Universiti Pendidikan Sultan Idris, Tanjong Malim, Perak \\ chintayuri@gmail.com
}

\begin{abstract}
ABSTRAK
Kemajuan pembangunan teknologi dan perisian yang memberangsangkan dalam evolusi animasi tempatan menular seiring dengan proses perkembangan intelektualisme kanak-kanak. Kekaguman dan ketinggian intelektualisme yang terkandung di dalamnya mempamerkan kerelevanannya dalam keupayaannya mengendalikan intelek kanak-kanak melalui pengalaman yang berbeza kualitinya berbanding kanak-kanak terdahulu. Objektif kajian ini dijalankan adalah untuk menganalisis pengurusan intelektualisme kanak-kanak melalui penampilan lucu watak animasi kartun tempatan, iaitu Upin dan Ipin (UI) berdasarkan kekuasaannya terhadap kanak-kanak. Kajian ini dijalankan dengan menggunakan Teori Hegemoni berlandaskan Prinsip Kepimpinan yang diutarakan dalam Pendekatan Pengurusan untuk diaplikasikan dalam memantapkan lagi kajian yang dijalankan. Pemaparan UI yang digarap berlatarbelakangkan masyarakat berbilang kaum di Malaysia memperlihatkan keupayaan pengurusan intelektualisme kanak-kanak melalui saluran hiburan animasi kartun. UI dilihat mempamerkan keupayaan memimpin kanak-kanak melalui keintelektualan watak di dalamnya berdasarkan penguasaan tanpa sengaja dan tiada paksaan. Hasil daripada kajian ini menjelaskan beberapa penemuan dapatan telah diperolehi. Kejayaan dalam pemerolehan dapatan sudah cukup untuk membuktikan eleman keintelektualan yang ditampilkan oleh watak dalam animasi ini amat signifikan untuk memperjelaskan keupayaan pengurusan intelektualisme. Kekuasaan UI ini dapat dimanfaatkan oleh kanak-kanak dalam persekitaran kehidupan seharian.
\end{abstract}

Kata Kunci: Animasi, Intelektualisme, Pengurusan, Prinsip Kepimpinan, Hegemoni, Keupayaan, Kekuasaan, Kanak-Kanak

\begin{abstract}
The advancement of technology and software development encourage the evolution of widespread local animation, in line with the process of children intellectualism development. The astonishing and highness of the intellectualism contained exhibiting the relevance in the capacity of handling children intellect via experiences with different qualities compares to the children of before. The objective of this research is to analyze the children intellectualism management through the appearance of amusing local animated cartoon characters, known as Upin and Ipin (UI); based on its leverage on children. This research will implement the Hegemony Theory, based on the Leadership Principal that has been in the centre of attention in the Management Approach, that later, its application is required to empower the research. The exposure of UI with the background of multiple races in Malaysia conveyed the capability of children intellectualism management over animated cartoon entertainment channel. UI manifests the ability to guide children through the characters' intellectualism in the story, based on involuntary and non-coercive mastery. The result of this research explains several discoveries have been made. The successful of acquisition of findings is sufficient to prove that the intellectual elements conveyed by the characters in this animation are significant to clarify the capability of intellectual management. The power of UI could be benefited by children in daily life environment.
\end{abstract}

Keywords: Animation, Intellectualism, Management, Leadership Principle, Hegemony, Capabilities, Power, Children 


\section{PENGENALAN}

Evolusi pembangunan animasi tempatan mendorong penggiat industri kreatif tempatan untuk menghasilkan animasi kartun yang mensasarkan kanak-kanak sebagai penonton setia. Skop animasi kartun kini bukan hanya tertumpu kepada pembikinan yang mengujakan, malahan diperkembang dan diaplikasikan bukan sekadar menghiburkan, tetapi terkandung di dalamnya unsur-unsur keintelektualan. Idea keintelektualan tanpa hiburan ibarat lagu tanpa irama bagi kanak-kanak. Penggunaan bahan kartun boleh dieksploitasi dalam bentuk refleksi peristiwa, dan penataran watak dengan menggunakan imaginasi berlandaskan alam nyata yang dipaparkan dalam bentuk alam maya. Bahan kartun ini juga dapat digunakan bagi mempertajamkan lagi keupayaan keintelektualan kanakkanak melalui kepimpinan watak dan peristiwa sebelum atau selepas tontonan.

Perubahan keupayaan kanak-kanak dalam meneroka pengalaman melalui dunia media membawa perhatian pengkaji terhadap animasi kartun Upin dan Ipin yang selepas ini akan dicatatkan sebagai (UI) dengan tanggapan awal, bahawa UI dilihat memiliki kepimpinan dalam upayanya menguruskan intelektualisme yang tersendiri terhadap kanak-kanak. Tanpa pimpinan, proses keintelektualan yang berlaku berkemungkinan tidak berkesan. Memimpin bukan suatu proses yang mudah dan memerlukan keupayaan untuk menguruskannya secara teliti. Pemimpin merujuk Tenas Effendy (2000) membawa pengaruh yang besar dalam kehidupan sehingga diberi kepercayaan, kekuasaan dan kebebasan untuk memimpin. Peredaran zaman mengalihkan pandangan masyarakat dari golongan cerdik pandai dalam mempengaruhi intelektualisme masyarakat kepada penguasaan sains dan teknologi seiring dengan kehidupan moden itu sendiri. Perubahan baharu ini sedikit sebanyak membentuk corak intelektualisme dan persepsi baharu dalam kehidupan masyarakat terutama bagi kanak-kanak (A.Aziz Deraman, 2005). Namun kini, kekuasaan animasi menghambat kanak-kanak untuk mudah teruja, terdorong dan terbimbing ini perlu disokong oleh kepimpinan animasi itu sendiri selagi tidak bercanggah dengan matlamatnya untuk membimbing, memimpin dan mendorong melahirkan masyarakat kanak-kanak yang terintelektualisme tanpa sengaja. Hal ini demikian kerana, perlakuan kanak-kanak yang terpimpin dengan kekuasaan UI dilihat sebagai satu proses menguruskan intelektualisme dan bukannya bersifat semula jadi.

Konsep pemikiran pada penjelasan Mok Soon Sang (2010) melihat golongan ini menganggap pengalaman dan pandangan orang lain adalah serupa dengan pemikirannya (hlm.124). Malahan, kanakkanak di peringkat ini tidak mempunyai kebolehan untuk membuat perbandingan dan tidak boleh melihat perubahan yang berlaku dalam sesuatu proses transformasi. Manakala, peralihan praoperasi 7 hingga 12 tahun, keupayaan berfikir kanak-kanak secara logiknya masih terbatas kepada konkrit sahaja tanpa kebolehan berfikir secara abstrak (hlm.125). Oleh itu, kanak-kanak pada peringkat usia praoperasi ini tidak dapat menyelesaikan masalah yang kompleks tanpa pimpinan. Maka, persoalan yang timbul ialah apakah prinsip pengurusan yang dapat mempengaruhi intelektualisme kanak-kanak dan adakah kekuasaan media itu dapat menguasai intelektualisme? Sehubungan itu, kajian ini mengupas pengurusan intelektualisme dalam kekuasaan animasi berdasarkan kepimpinan watak dan isu yang diketengahkan dalam UI. Terpesona akan kehebatan dan keunikan animasi kartun telah menarik perhatian kanak-kanak untuk mengangkat rancangan kartun sebagai model ikutan. Kanak-kanak dipertontonkan dengan rancangan kartun menarik tanpa mengira masa sehingga tanpa disedari kehidupan berkasih sayang si anak dirampas oleh kekuasaan animasi tanpa disedari. Perloff (1997) membuktikan bahawa kanak-kanak menganggap rancangan-rancangan di televisyen sebagai guru tanpa mempertimbangkan jalan cerita atau isi kandungannya. Kewujudan kuasa animasi ini cuba diselidik oleh pengkaji dalam melihat kekuasaan yang cuba ditonjolkan memandangkan keberadaan UI dalam dunia hiburan kanak-kanak diamati pada tanggapan awal berupaya menguruskan intelektualisme kanakkanak.

Melihat keperluannya, kartun mendidik dan menguruskan intelektualisme kanak-kanak dalam memahami keperibadian sosial dalam konteks yang menghiburkan tanpa adanya kuasa paksaan. Umum mengetahui, kanak-kanak yang didedahkan dengan sumber teknologi yang sihat akan meningkatkan perkembangan kognitif, emosi dan sosialnya (Mok Soon Sang, 2010: 74). Justeru itu, UI pada tanggapan awal dilihat sebagai model yang berupaya menguruskan intelektualisme kanak-kanak melalui kepimpinan watak dan dorongan yang tersembunyi. Kekuasaan $U I$ dilihat dapat menguruskan intelektualisme kanak-kanak untuk bertindak balas berdasarkan pengamatannya dalam pengalaman 
tontonan. UI model kartun yang bukan sekadar bercerita, namun mengandungi pengalaman yang dapat dikongsi bersama khalayaknya dalam simulasi masa nyata dan alam maya melalui saluran pernyataan intelektualisme kuasa media. UI tidak dianggap sebagai pengganti kepada hubungan kanak-kanak dengan dunia sebenar, tetapi kekuasaannya dipercayai dapat memimpin menguruskan keintelektualisme melalui pengalaman alam belajarnya, persekitarannya, dan dorongan pengalaman tontonannya di samping memperkembang intelektualisme kanak-kanak.

Tanggapan awal mendapati, melalui UI kanak-kanak terhegemoni dengan sendirinya berdasarkan kepimpinan watak dan isu yang diketengahkan dalam cerita tanpa perlunya penglibatan ibu bapa atau agen perantara atau petugas yang lain. Dalam konteks kanak-kanak, secara semula jadi minda mereka mudah dikawal dan dikuasai. Dunia tontonan seolah-olah menjadi guru kepada kanakkanak dengan memproses secara aktif bahan tontonnya (Perloff, 1997). Untuk memainkan peranan yang berkesan, media tontonan perlu dieksploitasi sepenuhnya dan bukannya bertindak hanya sebagai alat perantaraan. Media hiburan haruslah membantu memberi maklumat atau gambaran yang boleh dipercayai mengenai peristiwa yang berlaku di luar persekitaran (A.Aziz Deraman, 2005). Bertepatan dengan penjelasan Mok Soon Sang (2006), meskipun kanak-kanak hanya mampu menumpukan perhatian kepada satu situasi dalam satu masa tertentu, tetapi mereka akan memberi reaksi. Olahan apa yang dilihat dan apa yang didengar menyebabkan kanak-kanak mudah terpengaruh.

Dengan jelas, kanak-kanak tidak selalu mendengar nasihat, tetapi mereka akan cuba berimitasi dengan apa yang dilihat. Isu yang diketengahkan dalam UI diselesaikan melalui kebijaksaan kepimpinan watak-watak garapan pengarang seperti watak Opah, Tok Dalang, Cikgu dan kak Ros malahan, $U I$ turut mengetengahkan kepimpinan watak kanak-kanak dalam mendorong kanak-kanak lain bertindak. Merujuk A.Aziz Deraman (2005), masyarakat yang dibiarkan berubah tanpa pengarahan dan kepekaan kepimpinan lambat laun akan keliru tanpa arah (Hlm. 144). Melalui kepimpinan watak dalam UI, pengkaji pada tanggapan awal melihat kanak-kanak berupaya terarah dan terpimpin intelektualismenya. Rangsangan menguruskan intelektualisme tanpa dipengaruhi atau dihambat oleh kongkongan kuasa dan taraf, mendorong kanak-kanak untuk menguruskan setiap isu yang dihadapi. Peranan UI dalam menguruskan keintelektualisme kanak-kanak berdasarkan kepimpinan watak dan isu dalam $U I$ amat penting dalam pembinaan tamadun manusia hari ini. Bertitik tolak daripada kehebatan $U I$, pengkaji mengambil bahan animasi kartun ini sebagai bahan kajian.

\section{PERMASALAHAN}

Perkembangan pesat teknologi moden menjadikan lambakan animasi sebagai satu medium yang paling berpengaruh kepada kanak-kanak. Media memainkan peranan penting dalam menawarkan hiburan kepada kanak-kanak sebagai laluan mengisi masa lapang. Mohd Ariff dan Amala Salleh (2008), turut menjelaskan perkembangan teknologi telah diterima sebagai satu inovasi dalam proses pembelajaran dan pengajaran pada peringkat pendidikan awal kanak-kanak. Model behaviorisme pendidikan awal kanak-kanak juga turut memperlihatkan sifat semulajadi kanak-kanak yang gemar melakukan peniruan melalui pemerhatian dan mudah dipengaruhi. Sebagaimana diketahui umum, kanak-kanak tidak boleh hidup bersendirian tanpa dipandu. Pandangan Mahmood Nazar Mohamed (2001) dalam kajian Arbaie Sujud \& Nik Rafidah (2001) menjelaskan, kanak-kanak memerlukan bimbingan masyarakat sekeliling untuk mempelajari, mengetahui dan mengenali dunia di sekeliling mereka. Kanak-kanak perlu dibantu dalam menguruskan kehidupan melalui pengalaman singkat yang perlu dibimbing dengan bijaksana. Berpegang kepada pertimbangan kanak-kanak terhadap aksi menarik yang ditonton, ternyata dapat menggerakkan pengalaman animasi kemudiannya memuncakkan minat yang mendalam terhadap kartun yang ditonton. Kanak-kanak ternyata mengetepikan pertimbangan unsur bahasa mahupun isi cerita, memadai bahan yang ditonton dapat memenuhi kehendak selera kanak-kanak itu (Perloff, 1977).

Kartun kanak-kanak seharusnya membawa makna kehidupan secara tidak langsung. Melaluinya, kanak-kanak akan menimba pengalaman baru dalam mengenali alam nyata melalui alam maya. Bagi kanak-kanak, mereka terpaksa mengambil masa yang lama untuk menganalisis dan menyelesaikan sesuatu masalah dengan menggunakan daya pemikiran (Ahmad Esa et al, 2007: 8). Tanpa pimpinan, pengurusan intelektualisme kanak-kanak tidak akan berkembang dan kekreatifan intelektualisme mereka akan terbiar kaku dengan kekuasaan media. Oleh yang demikian, tontonan $U I$ 
tanpa kawalan ibu bapa atau orang dewasa cuba diangkat sebagai satu bahan moden yang berupaya mempengaruhi, mendidik dan menguruskan intelektualisme kanak-kanak sepertimana pengaruh penggunaan bahan bacaan seperti yang terkandung dalam kajian Arbaie Sujud dan Nik Rafidah (2001). Pandangan ahli-ahli teori konstruktivisme menegaskan bahawa, dalam pencapahan pemikiran, pelajar seharusnya dibimbing oleh guru ataupun bahan pembelajaran yang disediakan bagi memahami sesuatu konsep daripada pelbagai perspektif supaya pemikiran mereka berkembang dan dinamik (Jamalludin Harun dan Zaidatun Tasir, 2003).

Penjelasan Warren (1997) dalam pandangannya turut berpendapat bahawa, kawalan ibu bapa dalam tontonan rancangan pula dapat memberi manfaat sebagai agen pembudayaan positif tingkah laku kanak-kanak. Malahan, pandangan Warren (1997) turut disokong oleh pendapat Zulzaidi Mahmud (2008), yang menyarankan agar ibu bapa menemani anak-anak ketika menonton televisyen memandangkan kanak-kanak masih lagi berada pada tahap kesukaran untuk membezakan perkara baik dan buruk. Secara khususnya, penglibatan aktif ibu bapa amat penting dalam mempengaruhi keberkesanan mesej yang cuba disampaikan oleh media kepada kanak-kanak. Namun begitu, kajian Wan Anita \& Azizah Hamzah (2013) membuktikan bahawa, kebanyakan ibu bapa pada masa kini tidak mempunyai masa yang banyak untuk menjadi 'teman atau pengasuh' kepada penerokaan alam nyata anak-anak.

Namun, disebabkan sejumlah kajian animasi terdahulu tidak memfokus secara langsung kepada kajian intelektualisme kanak-kanak, pengkaji melalui kajian ini menggunakan Teori Hegemoni (Antonio Gramci) berlandaskan pendekatan pengurusan kepimpinan untuk melihat dan menganalisis keupayaan kanak-kanak menguruskan intelektualisme mereka melalui saluran kartun tanpa penglibatan ibu bapa atau golongan dewasa. Bertolak daripada besarnya pengaruh animasi kartun kepada kanakkanak, objektif kajian ini dilakukan pengkaji akan menjawab persoalan berkaitan pengurusan intelektualisme kanak-kanak yang dihasilkan menerusi animasi UI. Dalam hal ini, pengurusan intelektualime kanak-kanak dianalisis secara teliti berdasarkan kepimpinan watak dan isu yang terdapat dalam $U I$.

\section{OBJEKTIF}

Kajian ini dilaksanakan adalah untuk mencapai objektif-objektif seperti yang berikut iaitu untuk mengenalpasti kekuasaan $U I$ terhadap kanak-kanak dan menganalisis keupayaan isi kandungan UI yang dapat mempengaruhi intelektualisme kanak-kanak.

\section{METODOLOGI}

Secara umumnya, penyelidikan ini dijalankan dengan menggunakan kaedah kualitatif. Kajian ini menggunakan dua kaedah, iaitu kaedah penyelidikan kepustakaan dan kaedah análisis teks. Kajian ini dilakukan dengan berpandukan dua kaedah utama iaitu kaedah kepustakaan dan kaedah analisis dokumen atau teks. Pengumpulan data primer melalui kaedah kepustakaan diperoleh daripada buku, jurnal dan tesis. Pengkaji juga telah memanfaatkan penggunaan teknologi maklumat bagi memperoleh sebegitu banyak maklumat seperti jurnal, tesis dan artikel-artikel yang berkenaan melalui pengaplikasiaan internet. Kaedah analisis dokumen dilakukan dengan memilih transkrip yang bersesuaian dan melalui proses penayangan dan pembacaan teliti bagi mengenal pasti struktur yang relevan bersesuaian dengan unsur-unsur di bawah prinsip kepimpinan. Penelitian analisis memberi fokus utama terhadap struktur dalam transkrip iaitu watak dan isu yang diteliti dari segi tindakan dan pemikiran yang terkandung dalam episod-episod UI pilihan pengkaji.

Kaedah analisis teks dilakukan dengan melakukan proses penyisihan skrip $U I$ yang bersesuaian selepas proses tontonan dan transkripsi yang teliti bagi mengenal pasti struktur yang relevan dengan teori dan pendekatan kajian. Penelitian analisis teks akan memberi fokus terhadap struktur, iaitu watak isu atau peristiwa yang diteliti dari segi keintelektualan yang terkandung dalam penceritaan teks. Seterusnya, data dianalisis dan diperincikan dengan melihat isi kandungan transkrip. Kajian ini dibataskan dengan mengkaji transkrip animasi UI yang menjadi pilihan pengkaji. Pemilihan bahan 
berbentuk animasi iaitu tiga (3) episod $U I$ yang dipilih pengkaji adalah berdasarkan kesesuaiannya dengan teori dan objektif kajian yang dijalankan. Penelitian keseluruhan tiga (3) isi kandungan transkrip dari segi strukturnya bersesuaian dan relevan dengan prinsip kepimpinan. Pendekatan pengurusan yang diperkenalkan oleh Muhammad Mokhtar Hassan telah menggariskan lima (5) prinsip sebagai asas pegangan dalam prinsip pengurusan. Namun begitu, kajian ini hanya dibataskan dengan mengaplikasikan hanya satu daripada lima prinsip yang telah diperkenalkan iaitu prinsip kepimpinan. Rumusan kajian mendapati bahawa, melalui analisis karya tradisional ini pengkaji telah berjaya membuktikan bahawa aspek pemikiran pengurusan kepemimpinan Melayu tradisi menjadi kekuatan dalam kajian ini.

Berpegang kepada rumusan awal yang telah didampakkan oleh pengkaji terdahulu, pengkaji cuba mengetengahkan bahan kajian media yang lebih bersesuaian dengan peredaran zaman kanakkanak pada masa kini iaitu kepimpinan dunia animasi kartun dalam menghegemonikan tindakan dan menguruskannya tanpa sedar. Antara episod animasi $U I$ tersebut adalah seperti yang berikut:
a. $\quad$ Episod Raja Buah (RBm6ep9)
b. $\quad$ Episod Terbang tinggi-tinggi (TTTm5ep2)
c. Episod Cari dan Simpan (CSm9ep10)

\section{ANALISIS DAN PERBINCANGAN}

Perkembangan teknologi multimedia menjanjikan potensi besar dalam mengubah cara memperoleh, memproses dan menyesuaikan setiap maklumat yang diterima (Jamalludin Harun dan Zaidatun Tasir, 2003). Sejajar dengan perkembangannya, jika dalam proses pembelajaran pelajar berpeluang menentukan bentuk pengetahuan berdasarkan keperluan masing-masing dan mengalami suasana pembelajaran yang menarik dan berkesan, kehadiran kekuasaan animasi kartun turut mengikut jejak. Animasi kartun dalam kecanggihan teknologi media pula membuka peluang seluas-luasnya kepada kanak-kanak sebagai pemegang kuasa kawalan terbesar dalam menguruskan keintelektualisme yang diperoleh hasil dari tontonan. Pengurusan intelektualisme kanak-kanak bukan hanya terikat dengan teks semata-mata, tetapi lebih meluas. Perkembangan dunia animasi yang begitu pesat menjadi semakin popular dan menambat hati kanak-kanak dengan kedinamikan dan keunikan animasi UI yang membantu mempercepatkan proses pemahaman dan pengekalan informasi yang lebih panjang dalam ingatan. Bertepatan dengan pandangan (Jamalludin Harun dan Zaidatun Tasir, 2003), berdasarkan pendapat Vaughan (1998), pengguna yang tertarik akan memberi lebih tumpuan pada persembahan isi kandungan atau maklumat yang ingin disampaikan dan seterusnya proses penyampaian maklumat berlaku dengan lebih berkesan (hlm.29).

Di samping itu, proses pembelajaran menjadi semakin menarik apabila diselang selikan dengan eleman yang menghiburkan dan UI mampu memikat hati kanak-kanak ketika menonton. Kehadiran watak-watak yang melucukan merangsang intelektualisme kanak-kanak untuk mencari maklumat dan menyelesaikan setiap isu alam nyata yang berlaku menerusi konsep didikan dan hiburan alam maya. Dengan cara ini, proses pengurusan intelektualisme menjadi seronok dan menonton bukan lagi dianggap sebagai sesuatu yang membebankan minda kanak-kanak. Berdasarkan prinsip kepimpinan di bawah pendekatan pengurusan menjelaskan kepimpinan mempunyai satu pertalian dan hubungan yang erat dengan pengurusan (Mohammad Zuber Ismail, Sara Beden dan Mohammad Mokhtar Hassan (2015). Pemimpin merujuk Tenas Effendy (2000) lazimnya adalah orang yang dituakan dalam kehidupan. Pemimpin adalah perkara yang berbeza dengan kepimpinan. Pemimpin adalah orang yang diberi kedudukan menjadi ketua manakala, kepimpinan pula tidak memerlukan kedudukan atau pangkat.

Terdahulu, memetik dapatan kajian Zuraidah Abdullah, Zahir Ahmad dan Nuwairi Khaza'ai (2012), kepimpinan tidak boleh tidak membicarakan etimologi kepimpinan dalam alam Melayu. Kepimpinan turut memerihalkan keupayaan memimpin (Kamus Dewan Edisi Keempat, 2007). Menjengah pengertiannya pada hari ini, kepimpinan merujuk Zuraidah Abdullah, Zahir Ahmad dan Nuwairi Khaza'ai (2012) diberi pengertian yang lebih luas iaitu sebagai satu proses pengaruh terhadap gelagat, pemikiran orang lain malahan berperanan penting dalam menentukan prestasi tinggi atau rendah sesebuah institusi atau organisasi. Pandangan pengertian kepimpinan beralih kepada sarjana barat Certo (1997) yang melihat kepimpinan sebagai proses pengarahan tingkah laku orang lain ke arah 
penyempurnaan sesuatu objektif. Pandangan Certo menjelaskan, pengarahan bermaksud seseorang bertindak mengikut cara tertentu atau mengikut sesuatu seperti polisi, organisasi, tatacara dan deskripsi kerja. Tafsiran ini menunjukkan bahawa, kepimpinan saling berkait rapat dengan pengurusan yang pengertiannya merujuk Harold Koontz dan Heinz Weihrich (1997) dipaparkan sebagai kemahiran. Kemahiran ini dilakukan dengan menggunakan realiti sesuatu situasi yang berlaku.

Justeru, perbincangan ini akan meneliti episod-episod dalam UI yang menjadi pilihan pengkaji setelah proses penyisihan dilakukan. Penelitian selanjutnya memfokus kepada prinsip kepimpinan yang menggerakkan intelektualisme kanak-kanak melalui keterampilan watak dan isu yang diketengahkan dalam setiap episod pilihan. Keintelektualan kanak-kanak dalam kajian ini memfokus kepada lapangan pendidikan iaitu satu lapangan bagi kanak-kanak menjalankan proses dan aktiviti bagi memperkembangkan intelektualisme mereka. Mok Soon Sang (2010) merumuskan, pendidikan ialah suatu proses atau aktiviti yang berusaha untuk memperkembangkan fizikal, intelek, sosial dan emosi seseorang individu serta menambahkan kemahiran, pengetahuan, kebolehan dan pengalaman supaya dapat memberi kegembiraan, faedah dan kemajuan dlam kehidupan. Selanjutnya, dengan adanya pendidikan dapat membantu dan mendorong kanak-kanak untuk bertindak.

\section{Pengurusan Intelektualisme Berlandaskan Pendidikan Tidak Formal}

Limitasi kerangka kajian ini menunjukkan pembinaan intelektualisme kanak-kanak dilihat secara teliti berdasarkan isu dalam episod dan watak yang membinanya. Lapangan pendidikan dalam UI dikesan melalui kepimpinan watak dan isu dalam animasi yang membina keupayaan kanak-kanak untuk menguruskan keintelektualan mereka. Konsep pendidikan dalam UI yang digarap berlatar belakangkan budaya masyarakat Malaysia disesuaikan dengan perkembangan pesat karya animasi yang telah mencetuskan satu fenomena baharu dalam sastera kontemporari kanak-kanak. Kepimpinan watak memainkan peranan penting dalam perkembangan pengetahuan dan emosi kanak-kanak. Bandura (1977) menegaskan, kanak-kanak mempelajari sesuatu perlakuan melalui proses pemerhatian dan peniruan. Ini kerana, pada tahap umur sebegini kanak-kanak memulakan proses menguruskan intelektualisme dan amat dahagakan contoh sesuai yang boleh diikuti. Oleh yang demikian, kertas kerja ini ingin mengupas pengurusan intelektualisme kanak-kanak melalui penataran watak dan isu yang diketengahkan dalam setiap episod.

Sastera kanak-kanak amnya berfungsi untuk membentuk pemikiran, moral dan peribadi kanakkanak selain untuk mengembangkan imaginasi, pengetahuan dan kreativiti (Nasihah Hashim, 2015). Sastera kanak-kanak merangkumi semua jenis karya kreatif dan imaginatif untuk bacaan, hiburan dan penilaian kanak-kanak sama ada fiksyen dan bukan fiksyen (Hadijah Rahmat, 2006; Md Sidin Md Ishak, 2005). UI turut merupakan salah satu karya sastera kanak-kanak yang dihasilkan khusus untuk tontonan yang diketengahkan bukan sekadar menghibur, tetapi turut berupaya menguruskan intelektualisme kanak-kanak tanpa sedar akan wujudnya pengaruh kekuasaan dalam kepimpinan watak. Watak Opah, tok Dalang, Kak Ros dan Cikgu ditampilkan sebagai watak dewasa untuk menjadi sumber rujukan dan nasihat dalam mendidik kanak-kanak di samping membawa kepimpinan watak kanakkanak dalam memimpin tetapi dalam konteks yang berbeza iaitu memimpin sebagai dorongan. Aspek kelebihan inilah yang menjadikan UI kuasa yang sangat penting dalam menguruskan perkembangan intelektualisme kanak-kanak dengan sendirinya.

Realiti yang terpapar dalam alam maya dan karya sastera sangat berkait rapat. Melaluinya, kanak-kanak mula menguruskan intelektualisme melalui pembinaan maklumat kepimpinan watak dan dorongan isu dengan hanya berpandukan tontonan.Sifat ingin tahu dan suka bertanya kanak-kanak mendorong minat mereka terhadap alam sekitar atau sebarang perkara yang mereka dampingi (Jerome Bruner, 1966). Berdasarkan animasi UI, pengurusan intelektualisme kanak-kanak turut dipaparkan melalui pendidikan tidak formal seperti pengetahuan, pengalaman hidup, pemerhatian, pengamatan dan sikap suka bertanya. Paparan pengurusan intelektualisme berlandaskan pengetahuan dapat diperhatikan melalui petikan dialog Episod "Raja Buah" seperti yang di bawah: 
Tok Dalang : $\quad$ Ermmm...Nah...Cuba bau...Atok membawa sebiji durian ke

arah Upin dan Ipin...Sedap tak?

Upin ; Errmmm...erkkkkk....wek wekkkk...yekkkk

Tok Dalang : $\quad$ Apa la korang ni, kan sedap bau durian. Atuk pulak

mencium...erkkkkk...eehhhh...(nasib baik durian yang jatuh

dari tangan Tok Dalang tidak terkena kakinya...eh..fuhh...menarik nafas lega).

$\begin{array}{lll}\text { Upin } & : & \text { Nasib baik...Sedap bau Tok? } \\ \text { Ipin } & : & \text { Wangikan tok? } \\ \text { Tok dalang } & : & \text { Huh...Bau taik ayam...Menutup hidungnya. } \\ \text { Upin dan Ipin } & : & \text { Serentak...hahahahahaha }\end{array}$

Tok Dalang mencium sebiji lagi durian.Setelah menciumnya, dia mencampakkan durian itu. Ipin : Atok, kenapa buang?

Tok Dalang : : Durian mangkau

(Dipetik daripada RBm6ep9Bhg1)

Pengurusan intelektualisme bagi isu ini diperhatikan pada carta alir pengurusan yang berikut:

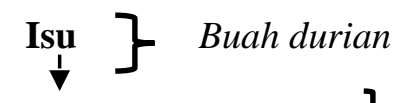

Pengetahuan (Intelektualisme dibina oleh watak Tok Dalang) $\begin{gathered}\text { Errmmm...Nah...Cuba } \\ \text { bau...Atok membawa sebij } \\ \text { durian ke arah Upin dan }\end{gathered}$
Ipin..Sedap tak?

Pertanyaan (Intelektualisme UI dibina)

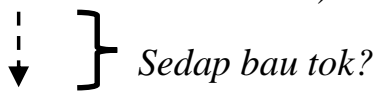

Pengalaman (Intelektualisme dibina oleh watak Tok Dalang)

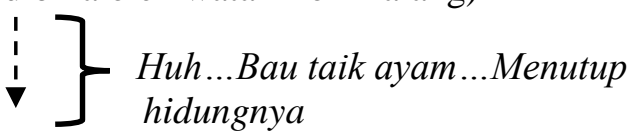

Pertanyaan (Intelektualisme UI dibina) Wangikan tok?

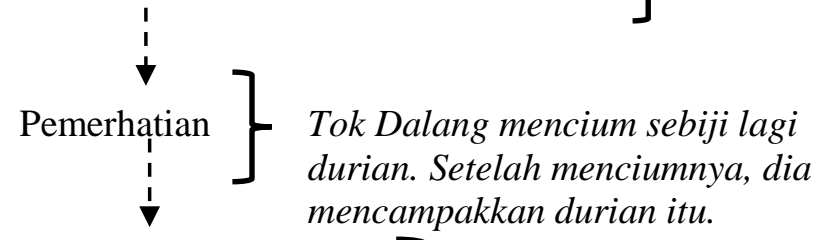

Pertanyaan (Intelektualisme UI dibina) $\}$ Atok, kenapa buang?

I

Pengalaman (Intelektualisme dibina oleh watak Tok Dalang)

Jurian mangkau

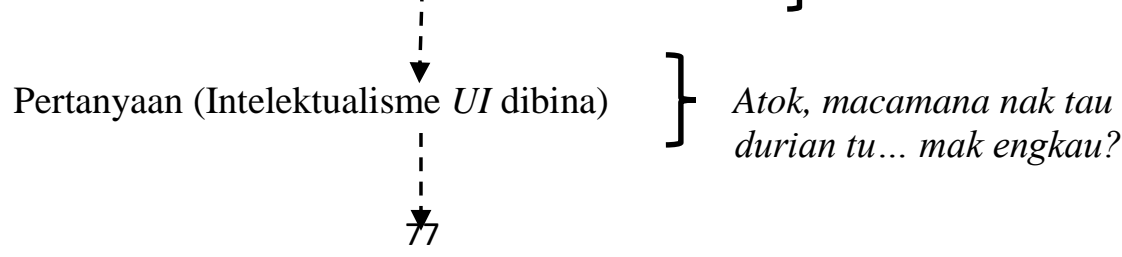


Pengalaman (Intelektualisme dibina oleh watak Tok Dalang)

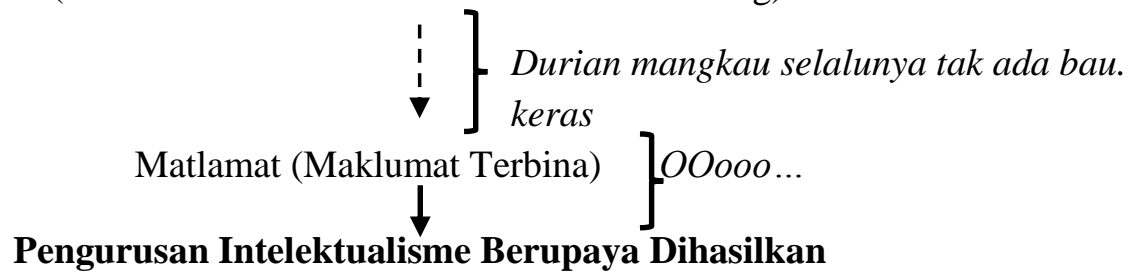

Pengurusan intelektualisme berlandaskan pendidikan tidak formal ini merujuk Mohamad Zuber Ismail, Sara Beden dan Mohamad Mokhtar Abu Hassan (2015) membentuk peribadi dan kebijaksanaan seseorang hingga pandai membawa diri (Hlm. 13). Rumusnya, apabila seseorang bijak membawa diri, maka tiada lagi sikap malu bertanya dan keinginan mendapatkan maklumat dan ilmu senitasa menjadi amalan. Segala tindak laku ini dilihat berdasarkan sikap Upin dan Ipin yang sentiasa bertanya untuk mendapatkan dan menguruskan intelektualisme mereka dapat diperhatikan dalam carta alir pengurusan intelektualisme bagi isu buah durian. Berdasarkan petikan dialog tersebut, mendapati watak Upin berupaya menguruskan intelektualismenya apabila berjaya mengetahui bau buah durian dan mengenali durian 'mangkau'. Pendidikan tidak formal bukan hanya meningkatkan ilmu pengetahuan Upin dan Ipin berkaitan buah durian malahan, melaluinya dipaparkan proses generasi muda menguruskan intelektualisme masing-masing bagi memenuhi tujuan hidup ysng lebih efisyen.

Bertunjangkan prinsip kepimpinan menerusi kekuasaan media adalah sangat signifikan menjadikan orang yang lebih berpengalaman seperti Tok Dalang yang terdapat dalam UI sebagai watak yang harus diamati.Watak yang berpengalaman seperti ini mampu membimbing khalayak generasi muda sepertimana pandangan Mohamad Zuber Ismail, Sara Beden dan Mohamad Mokhtar Abu Hassan (2015) yang menjelaskan, generasi terkemudian wajar akur dan mengambil perhatian kerana mereka orang yang berpengalaman. Paparan peristiwa di kebun durian turut memperlihatkan kepimpinan watak Tok Dalang yang berupaya menguruskan intelektualisme Upin dan Ipin dalam bentuk yang melucukan. Perhatikan contoh kelucuan yang berikut:

$\begin{array}{llll}\text { Upin } & : & \text { Atok, macamana nak tau durian tu mak engkau? } \\ \text { Tok Dalang } & : & \text { Mangkau... Durian mangkau selalunya tak ada bau. keras } \\ \text { Ipin } & : & \text { OOooo... }\end{array}$

(Dipetik daripada RBm6ep9Bhg2)

Kesinambungannya, kepimpinan berlandaskan pendidikan tidak formal ini sangat bertepatan dalam memimpin akal kanak-kanak daripada tersalah maklumat atau bertindak.

\section{Pengurusan Intelektualisme Berlandaskan Pemikiran Kreatif}

Kebolehan memperluas dan mengembangkan daya imaginasi dan kreativiti dengan tujuan untuk mendapatkan idea baru atau ciptaan yang asli dijelaskan oleh Mok Soon Sang (2008) sebagai pemikiran kreatif. Pemikiran berlaku kerana kewujudan rangsangan semasa keraguan dan timbulnya sesuatu masalah. Tujuan seseorang berfikir pula bertujuan untuk mentafsir rangsangan dengan membuat pertimbangan dan keputusan yang rasional terhadap msalah yang dihadapi. Upin dan Ipin adalah penimbulan watak yang berada pada praoperasi konkrit 7 hingga 12 tahun. Merujuk Piaget (1896-1980) dalam teori perkembangan kognitif kanak-kanak, pemusatan perhatian kanak-kanak mula memperoleh konsep transformasi melalui keupayaan berfikir secara logik tetapi masih terbatas kepada konkrit sahaja. Pemikiran kreatif mengikut Mok Soon Sang (2008) dijelaskan sebagai mengandungi keberanian untuk menjana idea baru tanpa kongkongan idea lama. Paparan pengurusan intelektualisme didikan kreatif dapat diperhatikan melalui petikan di bawah:

$\begin{array}{lll}\text { Tok Dalang } & : & \text { Ermmm... (sambil menggeleng kepala) } \\ & & \text { Mail...ko punya? Iskh... banyaknya? Nak buat apa ni? } \\ \text { Mail } & : & \text { Nak jual tok. Boleh buat duit. }\end{array}$




\section{(Dipetik daripada episod TTTm5ep2)}

Penelitian dalam petikan dialog ini memaparkan pengurusan intelektualisme melalui isu layang-layang. Diperhatikan melalui episod ini kanak-kanak lain hanya membataskan kehendak mereka kepada hanya menyiapkan layang-layang masing-masing, tidak begitu halnya dengan kepimpinan yang terpancar pada watak Mail (kanak-kanak). Lapangan pemikiran kreatif menjelaskan, watak ini berupaya menguruskan intelektualismenya dengan sendiri melalui dorongan sifatnya yang suka berniaga. Tanpa terkongkong dengan idea lamanya dengan hanya berniaga kepak ayam, Mail menggunakan kebijaksanaannya dengan menguruskan idea baru dengan menjual layang-layang. Malahan, kepimpinan watak Mail turut terserlah kekreatifannya melalui pemerhatian yang dilakukan ketika isu dorongan Upin dan Ipin dua beradik kembar ini mencari wang RM 1 setelah dicabar olah kakaknya (kak Ros). Umumnya, kanak-kanak hanya mengetahui watak Mail sebagai seorang yang suka berniaga dan barang perniagaannya adalah ayam panggang di pasar malam. Tetapi, setelah melihat kejayaan UI seperti contoh petikan di bawah berjaya menjual aiskrim dengan larisnya, berbanding dengan jualan ayamnya, Mail turut berminat untuk menjual aiskrim asalkan mendatangkan keuntungan dalam masa yang singkat. Mail berupaya menguruskan intelektualisme kreatifnya menerusi dorongan keseronokan Upin dan Ipin berniaga.

$\begin{array}{lll}\text { Mail } & : & \begin{array}{l}\text { Dua singgit dua singgit dua singgit...Ha, mari beli mari } \\ \text { beli... }\end{array} \\ \text { Upin dan Ipin } \quad: \quad & \text { Serentak...Mari-mari } 20 \text { sen } 20 \text { sen... ais krim } 20 \\ & \text { sen. Mari mari murah murah. Berteriak menjual } \\ & \text { aiskrim... }\end{array}$

Ramai orang mengerumini jualan Upin dan Ipin berbanding jualan ayam Mail. Akhirnya, aiskrim Upin dan Ipin habis dijual.

Upin dan Ipin : $\quad$ Serentak. Yeay...Mereka mengemas dan berjalan pulang melintasi gerai Mail.

Mail $\quad$ : $\quad$ Ha? Ermmm...Berfikir...Mak esok kita jual aiskrim lah.

(Dipetik daripada episod CSm9ep10)

Pengurusan intelektulisme kreatif Mail dapat dilihat berdasarkan rajah aras pengurusan berikut:

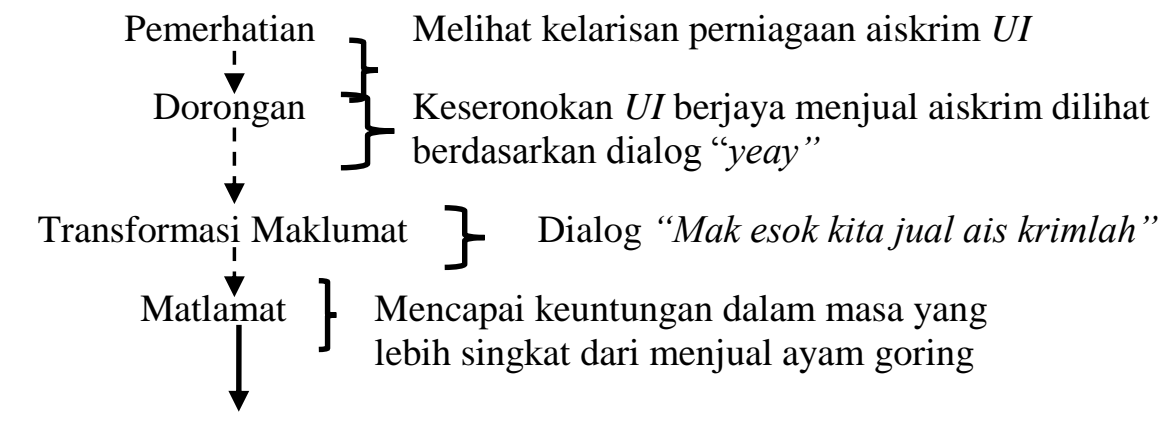

Pengurusan Intelektualisme Berupaya Dihasilkan

Kepimpinan watak Mail sebagai penampilan watak kanak-kanak turut mendorong watak Upin dan Ipin berusaha mendapatkan wang RM 1 sepertimana yang dicabar oleh Kak Ros. Pelbagai cara dilakukan oleh Upin dan Ipin untuk mendapatkan wang termasuklah membantu Mail berniaga menjual ayam di pasar malam. Petikan berikut menunjukkan kesungguhan watak Upin dan Ipin menggunakan intelektualisme kreatif mereka untuk mendapatkan duit melalui kepimpinan dorongan watak Mail. 


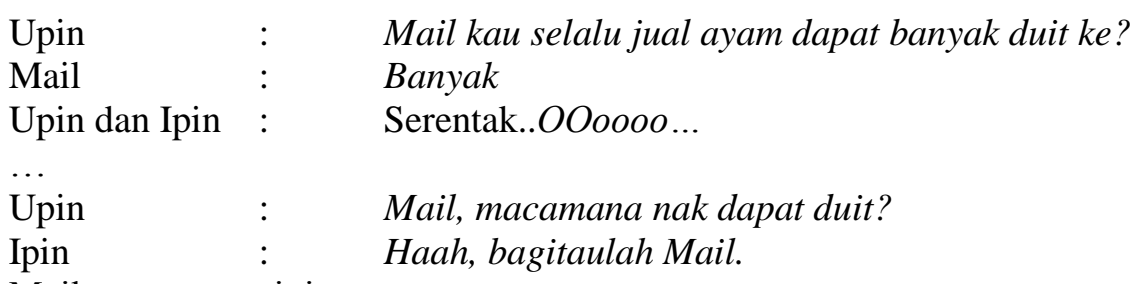

Mail tersenyum sinis...

(Dipetik daripada episod CSm9ep10)

Begitu juga dengan kekreatifan mereka berdua meminjam dari Ehsan seperti contoh dalam petikan yang berikut:

$\begin{array}{lll}\text { Upin } & : & \text { Ehsan. Engkau ada dua ringgit? } \\ \text { Ehsan } & : & \text { Aku ada empat ringgit. Sambil mengeluarkan duitnya. } \\ \text { Ipin } & : & \text { Ha, bagusla tu. Boleh pinjam dua ringgit? } \\ \text { Ehsan } & : & \text { Eh...tak boleh. Ini duit aku. } \\ \text { Upin } & : & \begin{array}{l}\text { Upin berusaha memujuk Ehsan. Ala bole la... Esok } \\ \text { kitorang bagi balik. Lepas tu aku belanja ABC. Ha, } \\ \end{array} \\ & \text { nak? }\end{array}$

(Dipetik daripada episod CSm9ep10)

Berdasarkan petikan pertama di atas menunjukkan, Upin dan Ipin meminta pendapat Mail cara untuk mendapatkan wang. Dialog serentak Upin dan Ipin "Oooooo" dengan jelas menunjukkan keintelektualisme Upin dan Ipin terbina kesan dari jawapan dari Mail "banyak". Secara tidak langsung kepimpinan watak Mail membina intelektualisme mendapatkan wang telah berjaya membina intelektualisme Upin dan Ipin tanpa sengaja. Mail turut memberi upah atas usaha upin dan Ipin membantunya menjual ayam di pasar malam. Walau bagaimanapun, keupayaan kepimpinan watak Mail dalam menguruskan intelektualisme Upin dan Ipin dalam isu mencari wang tidak berjaya apabila Upin mengeluh seperti dalam petikan dialog di bawah:

$\begin{array}{lll}\text { Upin } & : & \text { Huh... susahnya nak dapat singgit. Mengeluh. } \\ \text { Mail } & : & \text { Ha, tau tak pe. Nah...Mail memberi Upin dan Ipin } \\ & & \text { Sorang } 50 \text { sen. } \\ \text { Upin dan Ipin } & : & \text { Serentak.Ha? Terkejut. } \\ \text { Upin } & : & \text { Ni je? }\end{array}$

(Dipetik daripada episod CSm9ep10)

Pengurusan intelektulisme kreatif $U I$ dapat dilihat berdasarkan rajah aras pengurusan berikut:

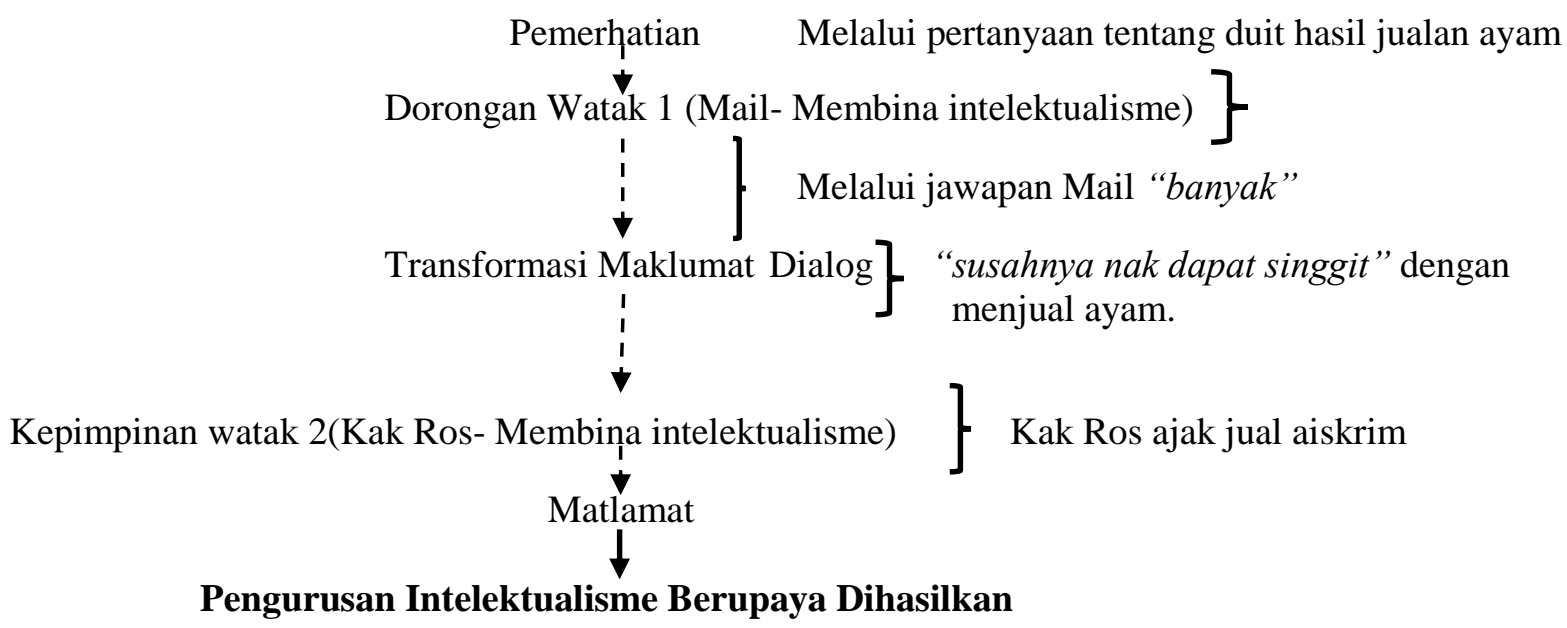


Merujuk carta alir pengurusan intelektualisme di atas menunjukkan bahawa Upin dan Ipin memerlukan dorongan tambahan disebabkan oleh watak Upin dan Ipin tidak berada dalam persekitaran berniaga tidak seperti Mail. Piaget menekankan bahawa, pengubahsuaian diri kanak-kanak dalam alam sekitar berlaku apabila seseorang itu memperoleh pengalaman daripada proses interaksinya dengan orang lain. Hal ini bertepatan dengan perihal pengurusan pemikiran kreatif Upin dan Ipin yang memerlukan dua dorongan watak kepimpinan iaitu Mail dan Kak Ros. Kekreatifan intelektualisme Upin dan Ipin dilihat daripada usaha mereka untuk menyelesaikan isu mencari idea bagi mendapatkan wang Rm1. Pada mulanya kekreatifan intelektualisme Upin dan Ipin didorong oleh kepimpinan watak 1 iaitu Mail (yang gemar berniaga).

Walaubagaimana pun, setelah mengalami pengalaman yang sukar hanya semata-mata untuk mendapatkan wang RM 1, watak Upin dan Ipin tidak mahu lagi berniaga, tetapi kehadiran dorongan watak 2 iaitu kak Ros memimpin watak Upin dan Ipin dalam menguruskan intelektualisme mereka dengan mengajak menjual aiskrim. Perubahan tingkah laku Upin dan Ipin yang sudah tidak mahu berniaga dilihat kesan daripada pengalamannya yang menolong Mail berniaga di pasar Malam berdasarkan dialog "Huh...susahnya nak dapat singgit. Mengeluh". Contoh petikan dialog berikutnya turut menunjukkan hasil daripada pengalaman sedia ada mewujudkan perubahan pada pengurusan intelektualisme Upin dan Ipin. Perhatikan contoh dialog berikut:

$\begin{array}{lll}\begin{array}{l}\text { Nah akak ganti. Kak Ros menunjukkan duit kertas RM } 2 \text { kepada adik-adiknya. } \\ \text { Upin }\end{array} & : & \text { Ini je? Beli aiskrim je habis. } \\ \text { Ipin } & : & \text { Betul betul betul... } \\ \text { Kak Ros } & : & \begin{array}{l}\text { Dari korang beli, baik buat sendiri. Tak payah pakai } \\ \text { duit.Boleh jual.Dapat duit simpan. }\end{array} \\ \text { Ipin } & : & \text { Macam susah je. } \\ \text { Upin } & : & \text { Hu hu.. mengangguk. } \\ \text { Kak Ros } & : & \begin{array}{l}\text { Susah susah...Tak cuba lagi dah kata susah. Ha... } \\ \text { meh kita buat sama-sama. }\end{array}\end{array}$

(Dipetik daripada episod CSm9ep10)

Hasilnya, jualan aiskrim Upin dan Ipin laris dan mendapat banyak wang seperti mana matlamat asalnya hanya berlandaskan isu mendapatkan wang RM 1 tetapi setelah wujudnya dorongan kepimpinan watak kedua membawa ke arah penabungan wang di bank sama seperti watak Mail yang menyimpan wang di bank. Kepimpinan watak Kak Ros juga berjaya membantu Upin dan Ipin menguruskan intektualisme mereka bagi isu sukarnya mendapatkan wang seperti dialog "Hiskh...akak ingat senang ke nak dapat duit?" dan "entah akak ni" dalam contoh berikut:

\begin{tabular}{|c|c|c|}
\hline Kak Ros & : & $\begin{array}{l}\text { Ha...duit yang korang simpan dalam sarung bantal akak } \\
\text { dah masukkan dalam akaun, siap tambah lagi yang akak } \\
\text { janji hari tu. }\end{array}$ \\
\hline Upin & : & Huh, akak ni, kitorang dah agak dah. \\
\hline Kak Ros & : & $\begin{array}{l}\text { Dah dah...Nah...memberikan adik-adiknya duit seorang } R M \\
\text { 1. }\end{array}$ \\
\hline Upin & : & Wahh ...dapat duit \\
\hline Kak Ros & : & Duit ni korang boleh belanja sesuka hati \\
\hline Upin & ; & Hiskh...akak ingat senang ke nak dapat duit? \\
\hline Ipin & : & Entah akak ni. \\
\hline Upin & . & Ipin, jomlah kita simpan dalam tabung. \\
\hline
\end{tabular}


Meneliti dapatan di atas menjelaskan keupayaan Upin dan Ipin menguruskan intelektualisme mereka terhadap isu mencari wang RM 1 setelah dicabar oleh kakaknya. Ringkasnya, pada permulaan isu intelektualisme Upin dan Ipin dibina menerusi kepimpinan watak Mail, tetapi setelah melalui pengalaman yang sukar, memunculkan kepimpinan watak kedua melalui watak kak Ros yang membina keintelektualisme Upin dan Ipin setelah kedua-dua kanak-kanak itu berjaya mentransformasikan maklumat berkaitan kesukaran mendapatkan duit melalui dialog yang berikut:

\section{Upin $\quad ; \quad$ Hiskh...akak ingat senang ke nak dapat duit? Ipin : Entah akak ni.}

(Dipetik daripada episod CSm9ep10)

Berbalik kepada tontonan, khalayak kanak-kanak melalui tontonan isu ini akan terhegemoni dengan sendiri dan berupaya menguruskan intelektualisme mereka apabila berhadapan dengan isu sama seperti tontonan dalam alam nyata. Kanak-kanak dapat menguruskan intelektualisme mereka dengan baik bagi mengendalikan isu yang berkaitan. Jika terdahulu kanak-kanak berdasarkan pengalaman sendiri melihat bahawa setiapkali menolong orang akan mendapat ganjaran, namun setelah menonton isu yang diketengahkan dalam episod ini, kanak-kanak yang menonton dapat membezakan pertolongan yang mendapat ganjaran dengan pertolongan yang dilakukan dengan ikhlas hati tanpa mengharapkan ganjaran. Kanak-kanak juga terhegemoni melalui pengalaman tontonannya supaya tidak selalu membazir memandangkan sukarnya mendapatkan wang sepertimana yang ditonjolkan oleh watak Upin dan Ipin.

Selain itu, pengurusan intelektualisme berlandaskan imaginasi turut diketengahkan pengkaji dalam dapatan kajian ini. Paparan tentang menguruskan imaginasi dalam intelektualisme dilihat menerusi kekuasaan kepimpinan watak Tok Dalang yang membina intelektualisme imaginasi watak Ipin dalam membentuk kendiri positif. Merujuk kajian Roger

Sperry (1981), otak kanan manusia melahirkan imaginasi. Perkembangan intelektualisme imaginasi Ipin didorong oleh kepimpinan watak Tok Dalang melalui dialog larangan seperti di bawah.
Tok Dalang :
Kanak-kanak :
Upin
Terkejut. Eh eh... jangan main sini.
serentak...Ha? Alaaa...
Tok Dalang : :
Kenapa pulak?
Nak main tu biar kat tempat lapang...Tak lah
layang-layang tu tersangkut.Sangkut kat pokok
tak pe jugak, kalau kat tiang letrik? Ha? Kan bahaya.

Mata Ipin menjeling ke arah tiang eletrik. Dia membayangkan bagaimana jika layang-

layang tersangkut dan dia mendapat kejutan eletrik.

(Dipetik daripada episod TTTm5ep2)

Keupayaan Ipin menguruskan intelektualismenya dengan jelas dilihat menerusi daya fikir imaginasi otak kanan Ipin terhadap padah akibat terkena kejutan eletrik. Inteletualisme Ipin terbina menerusi dialog "betul betul betul' yang menjelaskan pemahamannya terhadap kekuasaan larangan yang dikeluarkan oleh dialog kepimpinan watak Tok Dalang. Keintelektualisme Ipin berjaya dicapai melalui cantuman kekuasaan larangan watak Tok Dalang dengan cantuman imaginasi Ipin sehingga melahirkan fahaman baru. Carta alir pengurusan intelektualisme imaginasi Ipin dilihat seperti yang berikut: 
Dorongan (Watak Tok Dalang Membin $\left.\begin{array}{c}\text { Isu } \\ 1 \\ 1 \\ 1 \\ 1 \\ \vdots \\ \downarrow\end{array}\right\}$ Transformasi Maklumat (Imaginasi Ipin dibina )

Nak main tu biar kat tempat lapang... Tak lah layanglayang tu tersangkut.Sangkut kat pokok tak pe jugak, Kalau kat tiang letrik? Ha? Kan bahaya.

\section{Main layang-layang}

Mata Ipin menjeling ke arah tiang eletrik. Dia membayangkan bagaimana jika layang-layang tersangkut dan dia mendapat kejutan eletrik.<smiles>CCCCC</smiles>

\section{Pengurusan Intelektulisme Berupaya Dihasilkan}

Ringkasnya, hal-hal yang berkaitan aspek didikan yang diperjelaskan bersesuaian dan bertepatan dengan prinsip kepimpinan yang diketengahkan oleh Mohamad Mokhtar Abu Hassan (2013) di bawah pendekatan pengurusan. Berdasarkan pendekatan ini, jelas memperlihatkan bahawa pemimpin memainkan peranan yang penting dalam menguruskan intelektualisme kanak-kanak yang menonton berdasarkan pembinaan intelektualisme yang baik bagi kanak-kanak dan didikan berupaya dibina melalui aspek pengurusan yang berkesan. Tanpa kuasa paksaan watak pemimpin menguruskan intelektualisme kanak-kanak dengan bijaksana menerusi landasan pemikiran yang kreatif. Tiada unsur paksaan dilihat dalam dialog yang dipaparkan. Kanak-kanak diberi kuasa untuk menguruskan intelektualisme mereka sendiri berdasarkan dorongan isu yang dipaparkan.

Watak Kak Ros dan Tok Dalang diberi tanggungjawab dalam membantu kanak-kanak menguruskan intelektualisme kanak-kanak yang menonton. Paparan watak upin dan ipin yang menggunakan pemikiran kreatif dan imaginasi dilihat sebagai satu paparan pengurusan yang bijak. Hasil tontonan membuatkan, kanak-kanak dengan mudahnya terhegemoni dengan sendirinya tanpa paksaan daripada mana-mana pihak. Paparan isu Upin dan Ipin yang berusaha bersungguh-sungguh untuk mendapatkan wang RM 1 membawa kepada kepimpinan watak model dorongan dan ikutan (Mail) dan watak kepimpinan (Kak Ros) dalam memunculkan kekreatifan intelektualisme kanak-kanak. Malahan, imaginasi Ipin terhadap akibat direnjat eletrik jika layang-layangnya tersangkut, akan membawa kepada dorongan kanak-kanak yang menonton supaya tidak bermain di tempat yang sama agar tidak berlaku kejadian sepertimana yang telah diimaginasikan oleh otak kanan Ipin dalam isu ini.

\section{Pengurusan Intelektualisme Berlandaskan Personaliti (Emosi)}

Lapangan didikan dalam pengurusan intelektualisme kanak-kanak dalam UI bukan hanya memfokus dalam aspek intelektualisme pemikiran kreatif sahaja malahan UI turut menekankan pengurusan intelektualisme berdasarkan personaliti (emosi) melalui helah bela diri. Dalam konsep ini, kanak-kanak pada peringkat umur 7 tahun merujuk Piaget (1896-1980) tidak mempunyai kebolehan untuk berfikir secara abstrak. Oleh sebab itu mereka tidak dapat menyelesaikan masalah yang kompleks. Sehubungan dengan itu, pengkaji merujuk Sigmund Freud (1856-1939) dalam teori Psikodinamik menjelaskan, melalui pemikiran konkrit kanak-kanak menggunakan aktiviti tidak sedar yang dilakukan oleh ego. Aktiviti ego atau disebut sebagai 'helah bela diri' digunakan dengan tujuan untuk melindungi diri daripada ingatan, fikiran atau situasi yang merungsingkan. Merujuk dapatan dalam dialog di bawah menjelaskan, watak Ipin mengalami situasi yang merungsingkan. Melalui kekuasaan wataknya, tanpa sedar watak ini telah menggunakan 'helah bela diri' untuk menguruskan situasi rungsing yang dihadapinya. Isu wau Tok Dalang yang koyak dua bahagian sangat merungsingkan Ipin. Ipin cuba untuk menyalurkan kerungsingannya kepada watak Upin selaku abang. Lihat dialog yang berikut: 


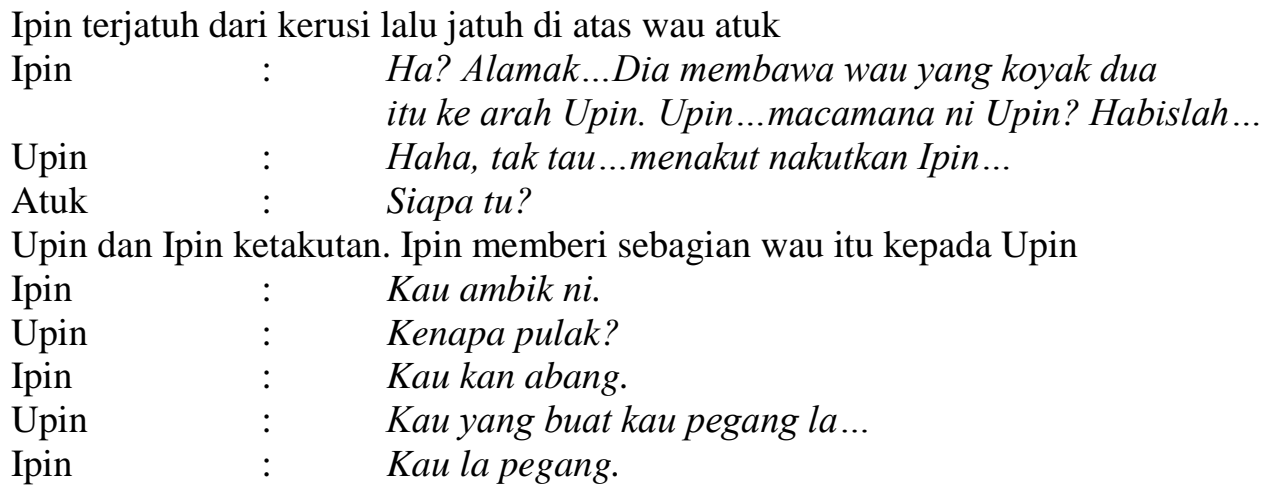

(Dipetik daripada episod TTTm5ep2)

Dalam dialog di atas jelas dilihat kesan dorongan negatif dari watak Upin menerusi dialog " $\mathrm{Ha} \mathrm{ha,} \mathrm{tak}$ tau..." benar-benar menakutkan Ipin. Ipin menguruskan helah bela diri melalui tingkah lakunya memberikan separuh wau yang koyak kepada Upin tanpa persetujuan Upin. Tingkah laku yang dilakukan oleh Ipin adalah satu cara atau taktik kanak-kanak menguruskan alasannya tentang tindakan yang dibuat. Tingkah laku Ipin adalah sebagai satu perlindungan diri terhadap sesuatu perbuatan yang berlaku iaitu wau yang koyak. Bagi Davidoff (1976) mekanisme ini hanyalah sebagai satu perlindungan atau pembelaan diri kanak-kanak terhadap sesuatu yang berlaku. Maka, helah bela diri ini diwujudkan oleh Ipin bagi usahanya menangani kebimbangannya takut dimarahai Tok Dalang.

Berikut dipaparkan aras pengurusan intelektualisme helah bela diri Ipin seperti yang berikut:

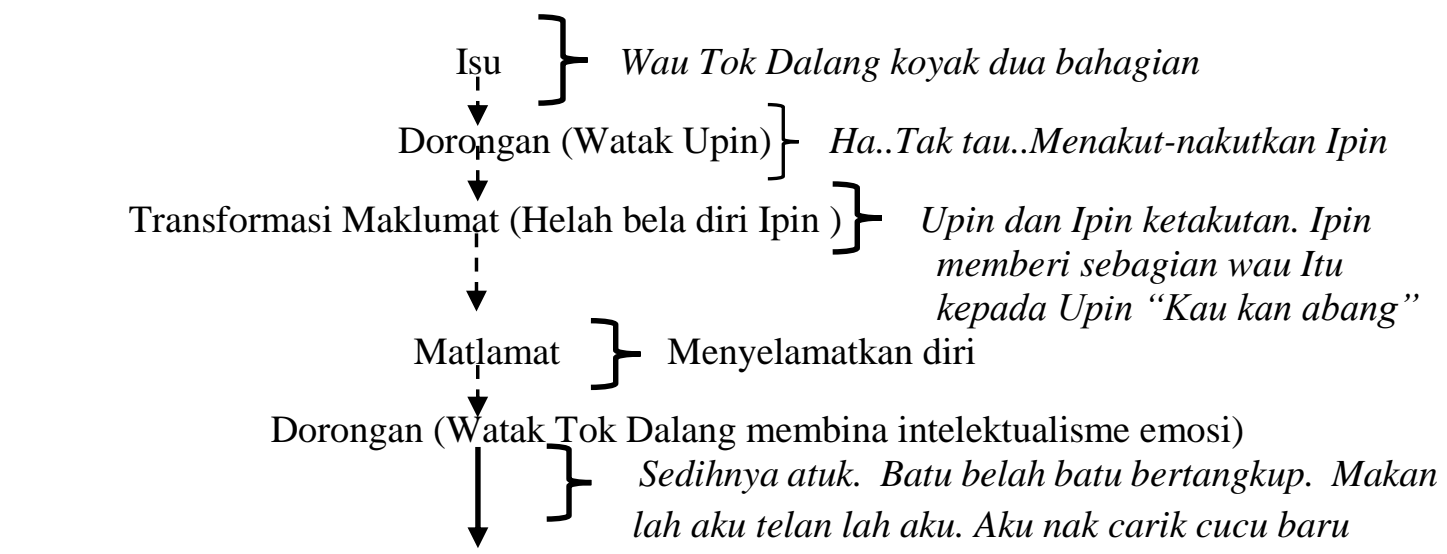

Pengurusan Intelektulisme Berupaya Dihasilkan

Lapangan pengurusan intelektualisme dalam episod ini memperlihatkan kebijaksanaan Ipin dalam menangani isu yang sedang berlaku. Walau bagaimanapun, helah bela diri yang digunakan oleh Ipin hanya berfungsi untuk menyelamatkan diri pada masa itu sahaja, mekanisme itu telah mewujudkan kendiri negatif dalam diri Upin dan Ipin yang tidak bertanggungjawab terhadap kesalahan yang telah mereka lakukan. Pemaparan kendiri negatif dalam episod ini akan memimpin kanak-kanak yang menonton ke arah satu contoh ikutan yang tidak baik. Dalam keadaan ini, jika seseorang menghadapi masalah, mereka haruslah mempamerkan keberanian untuk menjana idea yang pelbagai tanpa dikongkong oleh idea lama iaitu helah bela diri Ipin. Dengan berlandaskan pengurusan intelektualisme yang baik, Upin dan Ipin dengan fikiran terbuka menghasilkan idea yang baru untuk mengakui kesilapan setelah didorong oleh kepimpinan emosi watak Tok Dalang. Dalam episod ini, kepimpinan emosi watak Tok Dalang dipaparkan melalui bahasa badan iaitu bahasa bukan lisan. Perhatikan penataran cerita dan dialog berikut: 
Atuk terkejut melihat wau itu telah koyak dua.

$\begin{array}{lcl}\text { Tok Dalang } & : & \text { Ha????...terkejut... } \\ \text { Upin } & : & \begin{array}{l}\text { Atuk kenapa tok? Tok Dalang menyandar di tepi } \\ \text { dinding. ... }\end{array} \\ \text { Tok Dalang } & : & \begin{array}{l}\text { Sedihnya atuk. Batu belah batu bertangkup. Makan } \\ \text { lah aku telan lah aku. Aku nak carik cucu baru.... }\end{array} \\ \text { Tok Dalang } & : & \text { Buatlah apa yang korang suka. }\end{array}$

(Dipetik daripada episod TTTm5ep2)

Menyedari akan kesilapan masing-masing, watak Upin dan Ipin menguruskan isu dengan mengakui kesilapan. Lihat contoh berikut:

\begin{tabular}{|c|c|c|}
\hline Upin dan ipin & : & Serentak.ampun tok...ampun ... \\
\hline Upin & : & $\begin{array}{l}\text { Maafkan Upin tok maafkan Upin.Bukan Upin yang } \\
\text { buat. Ipin yang buat }\end{array}$ \\
\hline Ipin & & Tapi Ipin tak sengaja. \\
\hline Upin dan Ipin & & k-gerakkan lutut atuk. \\
\hline Upin & & Maafkan kami tok. \\
\hline
\end{tabular}

(Dipetik daripada episod TTTm5ep2)

Pengakuan salah Upin dan Ipin dapat memimpin intelektualisme kanak-kanak lain untuk belajar mengakui kesilapan tanpa paksaan. Hal ini demikian kerana, melalui bahasa badan Tok Dalang yang terduduk melihat waunya koyak membuatkan emosi Upin dan Ipin bertindak balas dari paparan negatif beralih ke arah paparan yang positif. Pengurusan intelektualisme berlandaskan paparan emosi ini merupakan proses kanak-kanak membina penghayatan emosi yang baik dan lebih sensitif terhadap perasaan orang lain (orang tua) atau disebut oleh Gardner (1983) sebagai empati. Keberjayaan intelektualisme Upin dan Ipin menguruskan emosi Tok Dalang membolehkan kewujudan hubungan yang baik antara Tok Dalang dengan dua beradik kembar ini. Piaget (1973) pula menambah bahawa, minda kanak-kanak berkembang mengikut usia dan mereka belajar memahami orang lain. Malahan, keupayaan pimpinan mereka berjaya menjadi bintang sanjungan dalam diri kanak-kanak yang menonton. Dialog di atas juga telah membina pengurusan intelektualisme Upin dan Ipin untuk membuat wau yang baharu bagi menggantikan wau yang koyak. Walaupun mereka berdua tidak didedahkan dengan cara membuat wau, tetapi hasil pemerhatian mereka ketika membuat layang-layang bersama Tok Dalang, mereka berdua mencuba bersungguh-sungguh untuk menggantikan wau tersebut. Berikut dipaparkan dialog Upin dan Ipin.

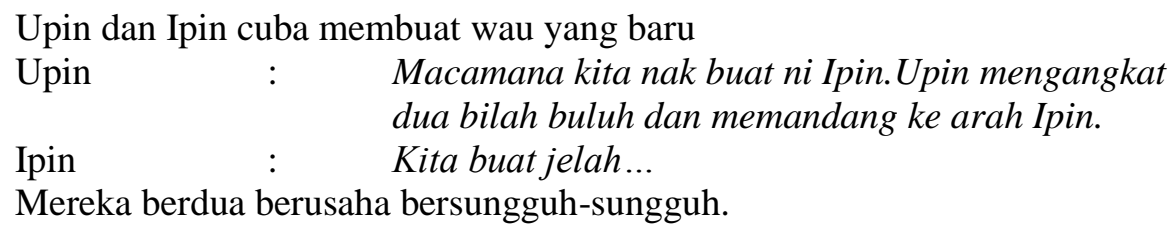

(Dipetik daripada Episod TTTm5ep2)

Ringkasnya, tanggungjawab yang dipamerkan oleh watak Upin dan Ipin merupakan usaha murni yang diambil oleh watak pemimpin untuk menjadi contoh yang baik kepada tingkah laku kanak-kanak lain.

\section{DAPATAN DAN RUMUSAN}

Perubahan baharu dan pengaruh mulitimedia animasi sedikit sebanyak telah membentuk corak intelektualisme baharu dalam masyarakat khususnya kanak-kanak. Zaman silam mencatatkan, sejarah intelektualisme Melayu tidak pernah mengetepikan pimpinan para ulama, karyawan dan budaya silam dalam mempengaruhi arah pemikiran pimpinannya. Perubahan baharu ini telah mngalihkan pandangan 
masyarakat dalam menguasai sains teknologi sejajar dengan perkembangan arus kemodenan yang menakluk generasi muda secara khususnya. Lantaran itu, melalui pengurusan intelektualisme yang digarap berlandaskan kepimpinan watak dan isu dalam episod UI pilihan ini amat signifikan khususnya dalam memimpin kanak-kanak menguruskan intelektualisme mereka secara tidak sengaja dan tanpa paksaan. Keintelektualisme generasi muda pemangkin negara ini terpimpin intelektualismenya dengan hanya menonton bahan media yang di dalamnya terkandung kebijaksanaan dan keintelektualisme kritis pengarangnya. Pengurusan intelektualisme yang ditanggapi dalam UI menjelaskan, manifestasi kepimpinan watak dan isu dalam menguruskan intelektualisme generasi cilik yang kini merentasi zaman dan peradaban. Sehubungan dengan itu, landasan didikan dalam UI sangat relevan dan signifikan dijadikan platform dalam mendorong kanak-kanak menguruskan intelektualisme mereka dengan sendirinya..

Desakan dunia modenisasi mengajak penonton ciliknya menggunakan kebijaksaan meneroka pengalaman sebenar melalui lambakan bahan dalam alam maya yang sama sekali pincang akalnya andai tiada pengurusan yang sempurna. Kanak-kanak pada dasarnya memerlukan pertimbanganpertimbangan dan refleksi yang logikal terhadap pencarian makna dan penyelesaian terhadap sebarang keraguan dan masalah yang timbul. Berdasarkan perbincangan di atas, jelas menunjukkan bahawa, kekuasaan media telah menguasai perjalanan hidup generasi muda ini melalui lambakannya yang tiada batasan. UI yang diketengahkan oleh pengkaji dilihat berupaya menguruskan intelektualisme kanakkanak melalui kebijaksaan kepimpinan watak dewasa dan ikutan dan dorongan watak kanak-kanak yang dipaparkan dalam penceritaan UI. Kebijaksaan watak memimpin bukan hanya dilihat pada pemaparan watak dewasa tetapi UI turut mengetengahkan watak kanak-kanak dalam bentuk pengawasan yang sewajarnya sepertimana keperluan kanak-kanak yang mendapat bimbingan dan perhatian ibu bapa di alam nyata.

Berdasarkan analisis kajian, di bawah kekuatan prinsip kepimpinan yang diketengahkan oleh Mohamad Mokhtar Abu Hassan dalam pendekatan pengurusan dan diperkukuhkan lagi dengan intelektualisme dalam teori Gramsci memperjelaskan kekuatan UI didampakkan berjaya mengekspresikan tanpa paksaan intelektualisme kanak-kanak dengan hanya menonton kuasa media tanpa perlunya pimpinan ibu bapa dan 'peneman dewasa' ketika menonton. Melalui tontonan, intelektualisme yang dipamerkan oleh watak-watak alam maya dalam menangani isu dalam setiap episode mendorong kanak-kanak dalam menguruskan intelektualisme mereka di alam nyata. Tanggungjawab ini adalah sebagai satu usaha menggantikan pimpinan ibu bapa semasa tontonan berlangsung. Tanpa ibu bapa, kanak-kanak mampu menguruskan intektualisme lereka sendiri melalui kekuasaan kepimpinan watak dan cara mereka menguruskan intelektualisme mereka sendiri sepertimana pemerhatian dan peniruan yang berlaku dalam episod UI. Keupayaan pengurusan intelektualisme kanak-kanak yang ditanggapi dalam animasi UI ini membuktikan kekuasaannya dalam menghegemonikan dan menguruskan intelektualisme kanak-kanak tanpa sedar dan tanpa paksaan melalui pembinaan maklumat dan kepimpinan watak dan isu yang mendorong cerita dalam setiap episod.

\section{RUJUKAN}

A.Aziz Deraman. (2005). .Asas pemikiran kebudayaan Malaysia. Kuala Lumpur: Dewan Bahasa dan Pustaka.

A.Aziz Deraman. (2005). Intelektualisme budaya. Kuala Lumpur: Dewan Bahasa dan Budaya.

Atan Long. (1976). Psikologi pendidikan. Kuala Lumpur: Dewan Bahasa dan Pustaka.

Atan Long. (1984). Pendidik dan pendidikan. Petaling Jaya: Fajar Bakti Sdn. Bhd.

Arba'ie Sujud, Nik Rafidah Nik Muhammad Affendi \& Asiah Abdul Rahman. (2001). Sastera Melayu satu pengantar edisi baharu. Kuala Lumpur: Tinta Press Sdn.Bhd.

Ary, Donald. (2002). Introduction to research in education. Belmont, CA: Wadsworth.

Azhar Hj.Wahid. (2015). Kritikan intelektualisme sastera Melayu.Tjg Malim: Universiti Pendidikan Sultan Idris. Bandura, A. (1997). Social learning theory. United States: New Jersey.

Brown H. Dougles. (1994). Principles of language learning and teaching. Englewood Cliffs: Prentice Hall.

Certo, S.C. (1997). Modern management: Diversity, quality, Eehics, and the global environment. New Jersey, Upper Saddle River: Prentice Hall.

Collin English Dictionary. (1995). Glasgow: Herper Collins Publisher. 
Edward W. Said. (1996). Kebudayaan dan kekuasaan; Membongkar mitos hegemoni barat. Terj. Rahmani Astuti. Bandung: Mizan. .

Gitlin, T. (1979). 'Prime time ideology: the hegemonic process in television entertainment'. Dalam New Comb, Horace, ed. (1994), Television: the critical view - Fifth Edition, Oxford University Press, New York.

Gramsci, A. (1971). Selections from the Prison Notebooks. London: Lawrence and Wishart.

Jamalludin Harun dan Zaidatun Tasir. (2005). Animasi dari helaian kertas ke skrin digital. Selangor: Ventor Publishing.

Hadijah Rahmat. (2006). Peranan dan perkembangan sastera kanak-kanak di Malaysia. Kuala Lumpur: Dewan bahasa dan Pustaka.

Hall, Edward Twitchell. (1981).The silent language. New York: Anchor Books.

Harahap, Oky Syeiful R. "Pengaruh Hegemoni dalam Dunia Pendidikan". Diperoleh daripada http://www.pikiran-rakyat.com/cetak/1204/02/1106.htm

Hollander, E.P. \& Offermann, L.R. (1978). Power and leadership in organizations: Relationships in transition. American Psychologist, 45 (2):179-189.

Kamus Dewan Edisi Keempat. (2007). Kuala Lumpur: Dewan Bahasa dan Pustaka.

Kerlinger, Fred N. (1973). Foundation of behavioral research. New York: Holt, Rinehart and Winston.

Koontz, H., Weihrich, H. (1997). Pengurusan. Kuala Lumpur: Dewan Bahasa dan Pustaka.

Levo-Henriksson, Ritra. (2007). Media and ethnic identity Hopi views on media identity and communication. New York: Routledge.

Maimunah Alias. (2010). Geng cetus fenomena luar biasa. Sinema Malaysia, 4 September. Diperoleh daripada daripada http:// www.sinemamalaysia.com.my/main/article/ GENG_Cetus_fenomena_Luar_Biasa_2767

Mescon, M.A. \& Khedouri, F. (1985). Management: Individual and organizational effectivenss. New York: Harper\& Rom.

Mok Soon Sang. (2006). Psikologi pendidikan untuk pengajaran dan pembelajaran. Selangor: Multimedia Sdn.Bhd.

Mok Soon Sang. (2008). Murid dan alam belajar. Selangor: Multimedia Sdn.Bhd.

Mok Soon Sang. (2010). Perkembangan kanak-kanak. Selangor: Multimedia Sdn.Bhd.

Mohamad Zuber Ismail, Sara Beden \& Mohamad Mokhtar Abu Hassan. (2014). "Prinsip kepimpinan: Analisis berdasarkan Hikayat Awang Sulung Merah Muda”. Dalam prosiding $3^{\text {rd }}$ International Language Conference (IIC), Centre For Languages And Pre-University Academic Development (Celpad), International Islamic University Malaysia (IIUM), $4^{\text {th }}-6^{\text {th }}$ Jun, 2014.

Muhammad Haji Salleh. (1989). Menyeberang sejarah: kumpulan esei pilihan. Kuala Lumpur: Dewan Bahasa dan Pustaka.

Muhammad Mokhtar Abu Hassan. (2013). Pendekatan pengurusan: Satu metode dalam kritikan sastera. Himpunan Ilmuan Sastera Melayu Malaysia Kedua Universiti Pendidikan Sultan Idris, 4-5 Oktober, 2013.

Noriati A.Rashid. (2005). Nilai kesantunan dalam konteks sosiobudaya masyarakat Melayu. Jurnal Pengajian Melayu, Jilid 15 Akademi Pengajian Melayu, Kuala Lumpur: Universiti Malaya.

Pengantar Hegemoni. (2005). Diperoleh daripada http://synaps.wordpress.com/2005/12/01/pengantar-hegemoni

Perloff, R. (1997). Mass media effects. United States: University of Virgin.

Pendidikan dan Latihan Animasi di Institusi Pengajian Tinggi Awam. Jurnal Pengajian Media Malaysia Jilid $12,12(2), 69-82$.

Piaget, J. (1973). Main trends in psychology. London: George Allen \& Unwin.

Robert Heinich et al. (2002). Instructional media and technologies for learning. Upper Saddle River: Merrill/Prentice Hell.

Rozinah Jamaludin. (2005). Multimedia dalam pendidikan. Kuala Lumpur: Utusan Publications \& Distributors Sdn. Bhd.

Simon, Roger.(1999). Gramsci’s Political Thought: An introduction. Yogyakarta: Pustaka Pelajar.

Syed Hussien Alattas. (1959). The intelectuals "Suara merdeka”. Jilid 10 no: 2: London.

Syed Hussein Alattas. (1992). Intelektual masyarakat membangun. Kuala Lumpur: Dewan Bahasa dan Pustaka.

Tenas Effendy. (2000). Pemimpin dalam ungkapan Melayu. Kuala Lumpur: Dewan Bahasa dan Pustaka.

Wyatt, A. (2010). The complete digital animation course: The principles, practice and techniques of successful digital animation. London: Thames \& Hudson.Ltd.

Zuraidah Abdullah, Zahir Ahmad dan Nuwairi Khazaii. (2012). Pantun dan ungkapan Melayu sebagai wahana kepimpinan Melayu ke arah pembangunan modal insan. Jurnal Edisi 9.PPBKKM. 